\title{
Nilai Moral dalam Dwilogi Novel Saman dan Larung Karya Ayu Utami
}

\author{
Endra Muplihun ${ }^{1)}$ \\ 1) SMPN 20 Singkawang \\ E-mail:endramuplihun@yahoo.co.id
}

\begin{abstract}
Abstrak. Novel Saman dan Larung merupakan sebuah novel yang berisikan potret peristiwa sejarah dan politik. Tentu saja di dalamnya terdapat nilai-nilai moral yang dapat diambil hikmahnya. Oleh karena itu, peneliti ingn mengetahui bagaimana nilai moral dalam dwilogi novel Saman dan Larung karya Ayu Utami? Metode yang digunakan dalam penelitian ini adalah metode deskriptif, bentuk penelitian kualitatif, dan pendekatan sosiologi sastra. Sumber data dalam penelitian ini adalah dwilogi novel Saman dan Larung karya Ayu Utami yang di dalamnya terdapat nilai-nilai moral sebagai objek penelitian hal ini dilakukan agar peneliti mampu memperoleh data sesuai masalah yang diteliti. Data yang diambil berupa kata-kata, kalimat, maupun wacana yang secara tersirat menandung nilai-nilai moral. Berdasarkan hasil analisis data, diperoleh tiga nilai moral dalam Dwilogi Novel Saman dan Larung karya Ayu Utami. (1) Nilai moral dilihat dari hubungan manusia dengan Tuhan. Nilai tersebut digolongkan menjadi: rasa takut akan Tuhan dan tidak percaya atau ragu akan Tuhan. (2) Nilai moral dilihat dari hubungan manusia dengan Masyarakat. Nilai moral kaitannya dalam hubungan manusia dalam masyarakat dibedakan mejadi: jujur terhadap orang lain, pertalian persahabatan, tolongmenolong, kewajiban mengabdi kepada orang lain atau melaksanakan kewajiban dan perintah, saling mengenal, dan penyimpangan seksual. (3) Nilai moral dilihat dari hubungan manusia dengan Individu (diri sendiri). Nilai tersebut dapat dibedakan menjadi: pengendalian diri, takut berdosa atau bersalah, senang hidup sederhana, berani mengakui dosa, percaya diri, berlaku adil, dan bertindak hati-hati.
\end{abstract}

Kata Kunci: Nilai moral, Sosiologi Sastra, dwilogi Saman dan Larung

\section{PENDAHULUAN}

Karya sastra merupakan pengungkapan pengalaman, pengetahuan, pikiran, perasaan, ide-ide, dan konsep-konsep nilai luhur, keyakinan serta nilai estetis. Aspek-aspek ini tumbuh berdasarkan konsep pemikiran yang matang sebagai sebuah kreativitas. Oleh karena itu, melalui karya sastra seseorang dapat mengatasi atau menghilangkan kesusahan, kepanikan, ketakutan, bahkan kegagalan. Karya sastra merupakan hasil karya manusia yang dituangkan dalam bentuk bahasa. Dalam karya sastra dijabarkan imajinasi dalam mengungkapkan kenyataan-kenyataan hidup yang dialami oleh tokoh-tokohnya. Kehidupan dalam karya sastra mirip dengan kehidupan nyata, karena karya sastra merupakan cerminan atas kehidupan lingkungan sekitarnya. Karya sastra juga merupakan pengungkapan hidup dan kehidupan yang dipadu dengan daya imajinasi dan kreasi seorang pengarang dengan dukungan pengalaman dan pengamatannya atas kehidupan tersebut. Pengalaman ini dapat berupa pengalaman langsung, yaitu yang dialami secara langsung oleh pengarang, dapat juga berupa pengalaman tak langsung, yaitu pengalaman orang lain yang secara tak langsung sampai kepada pengarang; misalnya, karena si pengarang banyak membaca. Kita harus memupuk dan menumbuh kembangkan apresiasi baca dan apresiasi sastra kepada anak-anak [8].

Moral dalam pengertian filsafat merupakan suatu konsep yang telah dirumuskan oleh suatu masyarakat untuk menentukan kebaikan atau keburukan. Moral merupakan suatu norma tentang kehidupan yang telah diberikan kedudukan istimewa dalam kegiatan atau kehidupan sebuah masyarakat. Karya sastra termasuk novel sangat tepat untuk memasukan nilai moral agar bisa mengembangkan imajinasi seseorang. Novel menceritakan berbagai masalah kehidupan manusia dalam interaksinya dengan Tuhan, interaksi manusia sesama manusia serta interaksinya manusia dengan Individu. Novel sebagai wujud sastra sedikit banyak memberikan gambaran terhadap kehidupan masyarakat. Bisa dikatakan demikian, sebab dalam novel memungkinkan kompleksitas masalah kehidupan manusia tersebut melalui tokoh, setting, dan tema atau unsur lainnya. Novel Saman dan Larung merupakan sebuah dwilogi karya Ayu Utami. Ayu Utami adalah seorang aktivis jurnalis dan sastrawan berkebangsaan Indonesia. Besar di Jakarta dan menamatkan kuliah di Fakultas Sastra Indonesia. Ia pernah menjadi wartawan di majalah Humor, Matra, Forum Keadilan, dan D\&R. Tidak lama setelah penutupan Tempo, Editor, dan Detik pada masa Orde Baru, ia ikut mendirikan Aliansi Jurnalistik Independen yang memprotes pembredelan. Kini ia bekerja di Jurnal Kebudayaan Kalam dan Teater Utan 
Kayu. Melalui novel pertamanya, Saman, namanya mulai dikenal sebagai novelis. Ia mendapat sambutan dan penghargaan dari berbagai kritikus. Karyanya dianggap mampu memberikan sumbangan dan warna baru dalam karya sastra Indonesia. Kemudian, berkat novel Saman juga, Ayu mendapat Prince Claus Award 2000 dari Prince Claus Fund, sebuah yayasan yang bermarkas di Den Haag, Belanda yang mempunyai misi mendukung dan memajukan kegiatan di bidang budaya dan pembangaunan. Selanjutnya, pada akhir tahun 2001, ia meluncurkan novel keduanya, yaitu Larung.

Karya Ayu Utami, khususnya Saman merupakan sumbangan penting dalam dunia sastra Indonesia menjelang reformasi. Hal tersebut ditadai dengan runtuhnya pemerintahan Orde Baru dan mundurnya presiden Suharto yang sudah berkuasa selama 32 tahun. Tentu saja novel ini menarik untuk dikaji dari aspek moral. Sebab lahirnya novel dwilogi ini berlatar belakang tidak jauh seputar kegiatan para aktivis yang malakukan pergerakan di berbagai bidang untuk membela masyarakat di kalangan bawah dalam menentang ketidak adilan. Novel Saman merupakan karya pertama Ayu Utami yang menjadi pemenang dalam lomba Sayembara Roman Dewan Kesenian Jakarta pada tahun 1998. Novel ini mengambil tema seksualitas dari perspektif perempuan yang masih tabu pada masa itu sehingga sedikit mengundang kontroversi. Cerita yang berlatar belakang Indonesia pada tahun 80-an dan 90-an pada masa rezim Orde Baru memerintah dengan otoriter. Tokoh-tokoh dalam novel ini bergulat dengan dalam kondisi sosial, politik, dan budaya Indonesia pada masa itu. Selain berlatar Indonesia, novel ini juga sedikit mengambil latar luar negeri, yaitu New York, Amerika Serikat.

Sedangkan Larung merupakan lanjutan dari novel Saman. Di penghujung Orde Baru. Novel ini dimulai dengan menceritakan pergumulan batin seorang lelaki muda berdarah Bali bernama Larung. Ia terkunkung oleh bayangbayang neneknya yang pesakitan. Niat membunuh seorang wanita tua yang sudah berumur begitu panjang, serasa wajar karena kehidupan nenek tersebut terlalu panjang untuk ukuran manusia normal.

Penelitian terhadap novel Saman dan Larung tentu sudah banyak dilakukan. Mengingat novel tersebut merupakan karya yang fenomenal tentu mengundang banyak ketertarikan. Akan tetapi, peneliti-peneliti terdahulu banyak focus pada kajian estetika, feminism, dan seksualitas dalam novel tersebut, sedangkan penulis ingin mengkaji dari aspek yang berbeda, yaitu nilai moral yang terdapat dalam dwilogi novel Saman dan Larung karya Ayu Utami.

Berdasarkan uraian latar belakang masalah di atas, penulis akan mengupas masalah karya sastra, khususnya berkaitan dengan apresiasi sastra novel. Agar terhindar dari penyimpangan masalah dan untuk mempermudah penulis dalam penelitian ini, maka ruang lingkup penelitian yang penulis lakukan perlu dibatasi. Masalah umum dalam penelitian ini adalah "Bagaimana nilai moral dalam dwilogi novel Saman dan Larung karya Ayu Utami?". Agar penelitian ini dapat dilaksanakan secara terarah dan terperinci, maka masalah tersebut dirumuskan kedalam sub- sub masalah: (1) bagaimanakah hubungan manusia dengan Tuhan dalam Dwilogi Novel Saman dan Larung karya Ayu Utami? (2) bagaimanakah hubungan manusia dengan Masyarakat dalam Dwilogi Novel Saman dan Larung karya Ayu Utami? (3) bagaimanakah hubungan manusia dengan Individu dalam Dwilogi Novel Saman dan Larung karya Ayu Utami? (4) bagaimanakah rancangan implementasi hasil penelitian terhadap mata kuliah Kajian Prosa Fiksi Indonesia pada Program Studi Pendidikan Bahasa dan Sastra Indonesia di LPTK?

Abrams (dalam Nugiyantaro, 2010) mengatakan bahwa novel berasal dari Inggris dan inilah yang kemudian masuk ke Indonesia-berasal dari bahasa Italia novella (yang berasal dari bahasa Jerman:novella). Secara harfiah novella berarti sebuah barang baru yang kecil. yang berarti sebuah karya prosa fiksi yang panjang cakupan, tidak terlalu panjang, namun juga tidak terlalu pendek. Wicaksono (2014) menyatakan bahwa novel adalah suatu jenis karya sastra yang berbentuk prosa fiksi dalam ukuran yang panjang (setidaknya 40.000 kata dan lebih kompleks dari cerpen) dan luasyang di dalamnya menceritakan konflik-konflik kehidupan manusia yang dapat mengubah nasib tokohnya [11]. Sayuti (1997) berpendapat bahwa novel (cerita rekaan) dapat dilihat dari bebera sisi. Ditinjau dari panjangnya, novel pada umumnya terdiri 45.000 kata atau lebih. Berdasarkan sifatnya, novel (cerita rekaan) bersifat expands, 'meluas' yang menitik beratkan pada complexity.Sebuah novel tidak akan selesai dibaca sekali duduk, hal ini berbeda dengan cerita pendek. Dalam novel (cerita rekaan) juga dimungkinkan adanya penyajian panjang lebar tentang tempat atau ruang [7].

Novel dibangun dari unsur-unsur yang saling berhubungan, dan pada akhirnya menjadi sebuah karya yang bermakna. Abrams (Nurgiyantoro, 2010) mengemukakan bahwa struktur karya sastra dapat diartikkan sebagai susunan, penegasan, dan gambaran semua bahan dan bagian yang menjadi komponennya secara bersama membentuk kebulatan yang indah. Unsur intrinsik adalah unsur-unsur yang secara langsung membangun karya sastra iitu sendiri [4]. Struktur dalam unsur-unsur intrinsik karya sastra meliputi: (1) tema, (2) latar (setting) (3) kerangka cerita (plot), (4) penokohan, (5) sudut pandang pengarang (point of view), dan (6) amanat. Aspek-aspek yang membangun karya sastra dapat ditinjau dari dalam maupun dari luar struktur karya sastra. Unsur ekstrinsik adalah unsur yang membangun karya sastra berdasarkan aspek di luar karya sastra. Berbeda dengan unsur intrinsik yang membangun karya sastra dari dalam karya sastra. Menurut Nurgiyantoro (2010), unsur ekstrinsik adalah unsur-unsur yang aspek analisisnyaberupa tinjauan dari luar karya sastra, tetapi secara tidak langsung mempengaruhi struktur yang membangun atau sistem organisme karya sastra.

Unsur ekstrinsik adalah unsur yang mempengaruhi karya sastra dari luar struktur karya sastra. Tujuan pengkhsusan sebuah nilai dalam penelitian sastra adalah supaya pembaca dapat memahami maksud diciptakannya sebuah karya sastra. Satu di antara unsur ekstrinsik dalam karya sastra adalah nilai moral berupa bentuk hubungan manusia dengan tuhan, 
bentuk hubungan manusia dengan sesama, bentuk hubungan manusia dengan alam. Secara umum moral menyaran pada pengertian (ajaran tentang) baik buruk yang diterima umum mengenai perbuatan, sikap, kewajiban dan sebagainya; akhlak, budi pekerti, susila (KBBI, 2003). Fiksi mengandung penerapan moral kehidupan yang diidealkannya. Fiksi mengandung moral dalam sikap dan tingkah laku para tokoh sesuai pandangannya tentang moral. Jenis ajaran moral itu sendiri dapat mencakup masalah, yang boleh dikatakan, bersifat tak terbatas. Ia dapat mencakup seluruh persoalan hidup dan kehidupan, seluruh persoalan yang menyangkut harkat dan martabat manusia. Poerdarminta (dalam Darmadi, 2012) menyatakan bahwa moral merupakan ajaran tentang baik buruknya perbuatan dan kelakuan [2]. Moral diartikan sebagai norma dan konsep kehidupan yang dijunjung tinggi oleh masyarakat. Nilai-nilai pendidikan moral tersebut dapat mengubah perbuatan, perilaku, dan sikap serta kewajiban moral dalam masyarakat yang baik, seperti budi pekerti, akhlak, dan etika [12].

Secara garis besar persoalan hidup dan kehidupan manusia itu dapat dibedakan dalam persoalan hubungan manusia dengan diri sendiri, hubungan manusia dengan manusia lain dalam lingkungan sosial termasuk hubungan dengan alam, dan hubungan manusia dengan tuhannya, Jenis hubungan tersebut dapat dirinci lebih khusus. sebuah novel tentu dapat mengandung dan menawakan pesan moral itu salah satu, dua, atau ketiganya sekaligus sekaligus, masingmasing wujud detil khususnya [4]. Wujud pesan yang terdapat dalam karya sastra mencakup seluruh persoalan yang menyangkut harkat dan martabat manusia. Secara garis besar persoalan hidup manusia itu dapat dibedakan dalam persoalan hubungan manusia dengan diri sendiri, hubungan manusia lain dalam lingkuangan sosial termasuk hubungannya dengan lingkuangan alam, dan hubungan manusia dengan Tuhannya [4].

Aspek hubungan moral manusia dengan Tuhan merupakan sebuah konsep perilaku manusia dalam hubungannya dengan tuhan. Sebagai makhluk ciptaan tuhan manusia diciptakan dengan akal budi yang menempatkan kedudukan manusia berada di atas makhluk-makhluk tuhan lainnya. Nilai moral yang berhubungan dengan masyarakat menyangkut hubungan antara manusia dalam kehidupan sosial. Manusia memiliki status dan peranan yang berbedabeda dalam masyarakat. Status atau kedudukan manusia dalam masyarakat dapat netral, tinggi, menengah, atau rendah. Nilai moral yang berhubungan dengan individu merupakan sebuah konsep sikap dan perbuatan manusia terhadap dirinya sendiri. Dengan demikian, persoalan yang menyangkut manusia dengan dirinya sendiri tidak lepas dari kaitannya dengan hubungan antara sesama manusia dengan Tuhan. Sikap individu merupakan kepribadian moral yang kuat dan dapat dilihat dari perilakunya sehari-hari. Sikap kepribadian moral itu meliputi "kejujuran, tanggungjawab, kemandirian, keberanian, dan kerendahan hati. Menurut Manan (dalam Aunurrahman, 2012) menyatakan bahwa pendidikan moral harus memperhatikan kepribadian secara menyeluruh, khususnya berkaitan dengan interaksi kita dengan orang laian, perilaku atau etika kita [1].
Sosiologi sastra berasal dari kata sosiologi dan sastra, istilah sosiologi sastra pada dasarnya tidak berbeda pengertiannya dengan sosiosastra, pendekatan sosiologis, atau pendekatan sosiokultural terhadap sastra [5]. Dasar filosifis pendekatan sosiologi sastra adalah adanya hubungan hakiki antara karya sastra dengan masyarakat. Hubunganhubungan yang dimaksudkan disebabkan oleh: a) karya sastra dihasilkan oleh pengarang, b) pengarang itu sendiri adalah anggota masyarakat, c) pengarang memanfaatkan kekayaan yang ada dalam masyarakat dan, d) hasil karya sastra itu dimanfaatkan kembali oleh masyarakat [5].

\section{METODE}

Metode yang digunakan dalam penelitian ini adalah metode deskriptif. Sukmadinata (2011) mengatakan penelitian deskriptif adalah suatu bentuk penelitian yang paling dasar. Ditujukan untuk mendeskripsikan atau menggambarkan fenomena-fenomena yang ada, baik fenomena yang bersifat alamiah ataupun rekayasa manusia [6].

Bentuk penelitian ini kualitatif. Menurut Gogdan dan Taylor (dalam Moleong, 1998), metodologi kualitatif sebagai prosedur penelitian yang menghasilkan data deskriptif berupa katakata tertulis atau lisan dari orang-orang dan perilaku yang dapat diamati [3].

Pendekatan yang digunakan adalah sosiologi sastra. Sumber data dalam penelitian ini adalah dwilogi novel Saman dan Larung karya Ayu Utami yang di dalamnya terdapat nilai-nilai moral sebagai objek penelitian hal ini dilakukan agar peneliti mampu memperoleh data sesuai masalah yang diteliti. Data yang diambil berupa kata-kata, kalimat, maupun wacana yang secara tersirat menandung nilai-nilai moral.

Teknik pengumpulan data dalam penelitian ini dilakukan dengan metode baca dan catat, dengan menyajikan data-data tinjauan sikap dan perilaku tokoh utama yang tercermin dalam pustaka amatan. Pengujian keabsahan data dilakukan dengan tiga cara: pengujuan kecukupan referensi, pemeriksaan oleh teman sejawat melalui diskusi, dan triagulasi. Teknik analisis data dilakukan secara deskriptif kualitatif interpretatif dengan pendekatan sastra murni, bertolak dari analisis aspek-aspek moral para tokoh.

\section{HASIL DAN PEMBAHASAN}

HASIL

Berdasarkan hasil analisis data, diperoleh tiga simpulan terkait nilai moral dalam dwilogi novel Saman dan Larung karya Ayu Utami. (1) Nilai moral dilihat dari hubungan manusia dengan Tuhan. Nilai tersebut digolongkan menjadi: rasa takut akan Tuhan dan tidak percaya atau ragu akan Tuhan. (2) Nilai moral dilihat dari hubungan manusia dengan Masyarakat. Nilai moral kaitannya dalam hubungan manusia dalam masyarakat dibedakan mejadi: jujur terhadap orang lain, pertalian persahabatan, tolong-menolong, kewajiban mengabdi kepada orang lain atau melaksanakan kewajiban dan perintah, saling mengenal, dan penyimpangan 
seksual. (3) Nilai moral dilihat dari hubungan manusia dengan Individu (diri sendiri). Nilai tersebut dapat dibedakan menjadi: pengendalian diri, takut berdosa atau bersalah, senang hidup sederhana, berani mengakui dosa, percaya diri, berlaku adil, dan bertindak hati-hati.

\section{PEMBAHASAN}

\section{Hubungan Manusia dengan Tuhan dalam Dwilogi Novel Saman dan Larung Karya Ayu Utami}

Nilai moral yang dilihat dari hubungan manusia dengan Tuhan dapat digolongkan menjadi beberapa hal sebagai berikut.

\section{Takut akan Tuhan}

Rasa takut akan Tuhan bagi orang-orang yang percaya kepada-Nya adalah rasa hormat terhadap Tuhan. Melalui rasa hormat tersebut membuat seseorang untuk tekun menjalani perintah dan larangan-Nya. Dan meyakini cinta kasih Allah kepadanya sehingga hanya kepada-Nya lah berserah dalam suka dan duka. Berikut akan dideskripsikan bagian-bagian dalam cerita tentang rasa takut tokoh akan Tuhan.

"Meski dokter tidak mampu menjelsakan apa yang terjadi, Sudoyo menganggapnya sebagai suatu anomaly pada tubuh manusia. Ketika bawahannya menawarkan mencarikan dukun, ia hanya berucap terima kasih. Aku hanya percaya Gusti Allah dan kekuatan doa." (Saman: 52)

Pada kutipan "Aku hanya percaya Gusti Allah dan kekuatan doa" menunjuk bahwa tokoh cerita takut akan Tuhan. Saat ditimpa kemalangan atau kehilangan anak dalam kandungan istrinya, ia tidak ingin berpaling pada yang lain atau dukun. Ia tetap mengandalkan kekuatan doa. Bahkan kehilangan anak dalam kandungan telah beberapa kali terjadi, tetapi Sudoyo tetap percaya pada kekuatan doa. Ia melaksanakan doa atau dalam istilah katolik misa arwah di rumahnya meskipun tanpa jenazah. Selanjutnya, "Keluarga itu mengadakan misa arwah, dan ibunya mengikuti prosesi seprti pendosa yang menyesal." (Saman: 52).

Berdoa dan memohon kepada Tuhan merupakan sikap manusia yang selalu percaya dan menaruh harapan pada Tuhan. Hanya kepada-Nyalah segala harapan akan disandarkan dalam keadaan apa pun. Berikut kutipan yang menyatakan tokoh dalam cerita berdoa dan memohon kepada Tuhan. "Misa arwah tanpa jenazah kedua kalinya." (Saman: 2013:52). Dalam kutipan lain, "Wis tak pernah mendengar bapaknya mengeluh. Lelaki itu bekerja tanpa pernah meminta kepada atasannya agar dipindahkan dari tempat yang melibatkan mereka pada kejadian tak megenakkan yang sulit dipahami. Ia berdoa tanpa pernah mempedulikan akankah Tuhan mengabulkan permintaannya atau tidak." (Saman: 54).

Kutipan di atas menyatakan kepercayaan seseorang yang sangat kuat pada Tuhan. Ia terus berdoa tanpa mempedulikan Tuhan akan mengabulkan doanya atau tidak. Tokoh dalam cerita (Sudoyo) benar-benar mengandalkan Tuhan dalam hidup dan keluarganya. Berdasarkan hasil wawancara pada Sabtu, 9 Januari 2016 Suster Flora juga berpendapat "Orang yang selalu berdoa dan mengandalkan
Tuhan dalam hidunya akan memproleh 'sesuatu'. Berdoa akan memberikan kebagaiaan, ketenangan, kekuatan, dan peneguhan." Selain itu, Ustad Nasution mengatakan "Manusia yang tidak berdoa pada Allah adalah manusia yang sombong. Oleh karena itu, berdoalah. Sebab dengan berdoa manusia berkomunikasi dengan Allah. Berdialog dengan Allah, serta yakinlah Allah akan mengabulkan permohoan kita." Jadi, orang yang selalu berdoa kepata Tuhan adalah orang yang tidal sombong. Dengan demikian, berdoalah Secara sungguh-sungguh dan penuh harapan adalah orang yang percaya pada Tuhan.

\section{Tidak Percaya atau Ragu akan Tuhan}

Ketidakpercayaan atau keragu-raguan diri seseorang kepada Tuhan dapat terjadi karena ketidakmampuan seseorang menghadapai suatu masalah dan menyebabkanya putus asa. Kemudian, beranggapan bahwa Tuhan tidak menolong tetap pada waktunya. Bahkan menganggap Tuhan tidak pernah ada. Selanjutnya, muncul lagi anggapan dalam diri seseorang bahwa segala yang dicapainnya adalah hasil kemampuannya sendiri bukan atas campur tangan Tuhan. Hal itu dapat terjadi pada siapa saja, demikianlah yang terjadi pada tokoh-tokoh dalam cerita Saman dan Larung.

"Ia merasa telah mati. Dan ia amat sedih karena Tuhan rupanya tidak ada. Kristus tidak menebusnya sebab ia kini berada dalam jurang maut, sebuah lorong gelap yang sunyi yang mencekam, dan ia dalam proses jatuh dalam sumur yang tak berdasar, dengan kecepatan tinggi." (Saman, 105). Dalam kutipan ini dapat diketahui bahwa Saman mengalami putus asa yang luar biasa. Padahal ia adalah seorang imam atau pastor. Dalam persoalannya ia tidak percaya akan penyelamatan.

\section{Hubungan Manusia dengan Masyarakat dalam Dwilogi} Novel Saman dan Larung Karya Ayu Utami

Pada dasarnya manusia tidak dapat hidup sendiri. Ia hidup berdampingan di tengah-tengah masyarakat. Dalam masyarakat tentu ada perilaku yang harus dijaga bersama, misalnya kejujuran, persahabatan, tolong-menolong, kewajiban mengabdi kepada orang lain, dan hubungan (pergaulan) yang menyimpang. Berikut akan dideskripsikan nilai moral dalam hubungan manusia dalam masyarakat.

\section{Jujur terhadap Orang Lain}

Jujur merupakan sifat yang tidak curang, mengikuti aturan yang berlaku, lurus hati atau berkata apa adanya terhadap orang lain. Apa bila seseorang seseorang menyeleweng atau menyembuyikan sesuatu dapat dikatakan bahwa orang tersebut tidak jujur. Dalam cerita terdapat beberapa kasus penyelewengan, tidak berkata jujur, seperti melakukan hubungan perselingkuhan. "Yang pertama adalah Sihar Situmorang, insinyur analisis kandungan minyak, orang yang membuat Laila tertarik karena ketidakacuhannya dan postur tubuhnya yang liat" (Saman: 11). Di sini Laila, tertarik dengan tokoh Sihar, seorang lelaki Batak yang sudah beristri.

"Ia menatap saya. Kini ia menoleh ke mata saya yang duduk di samping Rasono, meski hanya sebuah kontak psikis yang singkat. Seperti malu-malu, seperti orang yang sombong, seperti cowok cuek. Ia beralih ke baki saya, dan menyapa. 'Makannya sedikit sekali.' Sihar Situmorang. Dia 
tersenyum." (Saman: 12). Perasaan tertarik Laila bersambut oleh Sihar.

\section{Pertalian persahabatan}

Pertalian perahabatan juga terjadi pada tokoh Anson dan Saman. Anson adalah penduduk dusun rumpang (saudara kandung Upi), “Anak muda itu membopong Wis bergantian. Dalam perjalanan Anson bercerita bahwa ia telah berencana membakar pabrik sawit yang baru dibangun itu, tanpa tahu bahwa Wis disekap di dalamnya." (Saman, 112). Pada kutipan ini sebenarnya selain hubungan persahabatan Anson dan Wis, juga ingin diceritakan soal balas dendam yang dilakukan Anson terhadap pemilik perusahaan sawit dan atas kehilangan sahabatnya, Wis.

\section{Tolong-menolong}

Pada dasarnya ketika manusia hidup berdampingan di masyarakat, sudah seharusnya ia hidup saling tolongmenolong. Sikap saling menolong dapat kita temukan pada kutipan berikut.

"Jangan terlalu merasa bersalah karena melarikan diri. Kemarin saya baca wawancara Amosi dengan Tempo dari suatu tempat persembunyian. Dia juga melarikan diri sama seperti kamu. Dia bilang, dia melakukannya selama ini, jika ada demonstrasi, selalu ia ditangkap lalu dianiaya tanpa tahu kesalahannya. Hampir semua kantor LSM di sekitar Medan sekarang kosong. Semua orang tiarap. Teman-teman yang ditangkap memang disiksa. Sampai hari ini tuduhan masih subversi. Dalam situasi begini. Menghindar adalah pilihan yang baik." (Saman:176).

Kutipan di atas adalah surat yang dikirim Yasmin kepada Saman. Menceritakan pelarian Saman dan kasus penyerangan terhadap LSM di Medan. Yasmin merencanakan dengan baik proses pelarian Saman sehingga Saman tiba ke New York tanpa hambatan.

\section{Kewajiban Mengabdi Kepada Orang Lain atau} Melaksanakan Kewajiban dan Perintah

Hidup berdampingan di masyarakat kadang membuat seseorang harus mematuhi norma yang ada. Dalam hidup bermasyarakat juga terdapat kewajiban yang harus kita jalankan. Kewajiban tersebut terkadang memiliki hubungan dengan orang lain seperti bekerja sehingga apa yang kita lakukan atau kerjakan membuat seseorang seolah wajib mengabdi kepada orang lain. Hal itu juga terjadi pada tokoh dalam cerita. Berikut akan dipaparkan kutipannya.

"Dia adalah satu di antara tiga lelaki yang berada dalam cahaya yang masuk dari tiga jendela di atas altar." (Saman: 40). Pada kutipan ini diceritakan tiga orang lelaki yang akan memasuki altar dalam gereja. Mereka akan segera ditabiskan untuk menjadi imam. Jika seseorang telah memilih panggilan hudupnya untuk menjadi imam, maka ia wajib mengabdikan hidupnya bagi gereja dan melaksanakan perintah yang ada. Begitulah "panggilan hidup" yang dijalani oleh Saman yang semula bernama Athanasius Wisanggeni.

\section{Saling Mengenal}

Manusia diharapkan saling mengenal, sehingga terjalin hubungan baik dalam hidupnya, harus saling membantu karena dalam kenyataannya tidak ada orang yang bias hidup sendiri tanpa ada bantuan orang lain. Begitulah yang terjadi pada tokoh-tokoh dalam novel ini. Wis (pada waktu itu adalah pastor baru) yang nanti akan berganti nama menjadi Saman amat merindukan rumah masa kecilnya. Ia dating kembali ke rumah itu, tetapi rumah itu sudah ditempati orang lain. Wis berkenalan dengan penghuni rumah itu dan berharap mereka bisa membantunya untuk kembali ke rumah masa kecilnya yang menyimpan misteri belum terpecahkan.

"Wis terkejut, tak siap menghadapi orang lain di rumah masa kecilnya, tak siap menjadi orang asing di bekas tempat tinggalnya. Dan wanita itu hamil tua, seperti Ibu ketika hidup di situ. Untuk beberapa detik, Wis tak bisa berkatakata." (Saman: 60) Kutipan tersebut merupakan pertama kali Wis berkenalan dengan penghuni rumah masa kecilnya. Wis menyapa hingga akhirnya mereka saling mengenal.

\section{Penyimpangan Seksual}

Manusia diciptakan berpasangan. Pria dan wanita untuk saling melangkapi. Dalam cerita ini terjadi penyimpangan seksual yang terjadi pada tokoh Shakuntala dengan sahabatnya Laila. Berawal dari rasa kasihan Shakuntala dan rasa kecewa Laila terhadap Sihar (seorang lelaki yang sudah beristri). Shakuntala yang dalam dirinya terdapat sisi yang lain, yaitu dirinya yang lelaki. Untuk memperjels, berikut dapat di lihat kutipannya.

"Ada diriku di tempat yang lain yang aku tidak ingat tetapi yang mengingat aku. Itu membuatku murung." (Larung: 168). Kemudian, ada kutipan lain yang sangat mendukung bahwa Shakuntala memiliki sosok lelaki dalam tubuhnya. Hal itu digambarkan pengarang seperti ini: "Kemudian bertahun-tahun lelaki dalam diriku tak pernah kembali. Inilah saat-saat murungku: bawa aku tak ingat, tak bias ingat, adakah aku menemui dia dan bermesraan dengannya di masa-masa ini. Barangkali kemarin. Barangkali besok. Apa yang membuat diri kita satu jika kita tidak bias mengingat bagian-bagiannya?" (Larung:168).

Hubungan Manusia dengan Individu (diri sendiri) dalam Dwilogi Novel Saman dan Larung Karya Ayu Utami

Nilai moral individual merupkan adanya hubungan manusia dengan dirinya sendiri. Dalam hal ini, kita dapat melihat bagaimana perasaan yang sedang dihadapi manusia atau tokoh dalam cerita ketika menghadapi persoalanpersoalan hidupnya. Adapun permasaahan yang dapat dilihat sebagai berikut.

\section{Pengendalian Diri}

Marah merupakan rasa tidak senang yang dirasakan seseorang terhadap suatu hal seperti perkataan, perbuatan, atau tidakan. Rasa marah juga terjadi akibat dari ketidakmampuan seseorang dalam menahan rasa marah atau emosi negatif. Dalam novel Saman rasa marah dialami tokoh yang bernama Sihar. "Sihar terus memukuli bangku mika di bandara yang kecil, sehingga kulit ari dari bukunya lecet. Berdarah jingga tua. Aroa asin laut meraupi pulau sempit itu, dari sisi satu ke sisi yang lain. Ia begitu marah dan meyesal karena tidak menghajar Rasono hingga pingsan untuk mencegah kecelakaan yang sudah diperkirakan." (Saman: 17).

\section{Takut berdosa atau bersalah}

Rasa takut berdosa atau bersalah sering terjadi pada setiap orang. Hal tersebut biasanya terjadi ketika seseorang 
merasa perbuatan atau perilakunya melanggar norma atau atauran yang berlaku. Rasa takut berdosa atau bersalah juga dialami oleh beberapa tokoh dalam cerita. Berikut kutipannya.

"Saman,

Forgive me. Pease. Setelah kamu keuar dari diosesan, setelah kamu mengganti nama dan penampilan, setelah sering kamu meragukan keadilan Tuhan, bahkan keberadaan Tuhan, aku tidak menyangka kalau kamu masih punya keinginan kembali menjadi pastor. Aku tidak tahu bagaimana harus minta maaf, sampai-sampai dua hari ini aku tidak berani membalas suratmu. Aku menyesal sekali. Apakah kamu menganggap aku Hawa yang menggod Adam?" (Saman: 187)

Kutipan di atas merupakan surat dari Yasmin yang dikirimkannya kepada Saman. Perasaan bersalah yang dirasakan oleh Yasmin kerena sudah menggoda Saman. Yang semula ia adalah seorang imam tetapi sudah memutuskan untuk tidak menjadi seorang imam lagi karena beberapa hal. Di samping itu, Yasmin juga merasa bersalah karena ia sudah bersuami. Ia mengkhianati sumainya-Lukas.

\section{Senang hidup sederhana}

Sederhana adalah sifat seseorang yang tidak berlebihlebihan dalam menggunakan sesuatu, melakukan sesuatu, atau berkata tentang sesuatu. Pada kenyataannya tidak semua orang mampu hidup sederhana. Setiap orang cenderung ingin hidup mewah. Mengikuti trand, terkadang sampai merebut hak milik orang lain untuk memenuhi kebutuhannya. Dalam cerita ini hal tersebut tergambar pada kutipan berikut.

"Bapaknya tak memiliki darah ningrat dan memilih nama Sudoyo ketika dewasa. Lelaki itu berasal dari Muntilian dan beragama ketet, agak berbeda dari sang ibu, meskipun ke gereja pada hari Minggu, juga merawat keris dan barang-barang kuno dengan khidmad. Sudoyo anak Menteri Kesehatan. Ia menjadi pegawai Bank rakyat Indonesia di Yogyakarta sejak masih kuliah ekonomi di Universitas Gadjah Mada. Wisanggeni lahir di sana. Saat umurnya enam tahun, Bapaknya dipindahkan ke Parabumulih, sebuah kota seberang yang panjang jalannya kira-kira cuma lima kilometer." (Saman: 46)

\section{Berani Mengakui Dosa}

Berani mengakui dosa adalah perbuatan yang jujur. Jujur terhadap diri sendiri, maupun orang lain. Jika seseorang menyadari atau mengakui dosa, maka ia mengenali kesalahan. Dan kemungkinan akan berusaha untuk meninggalkan dosa tersebut dan bertobat. Berikut kutipan tersebut:

"Ia sering merasa berdosa pada istrinya. Semakin lama itu semakin menghantuinya, sehingga suatu hari saya begitu kesal sebab beberapa kali ia membatalkan janji karena rasa bersalahnya, dan saya berkata, "Ternyata kamu laki-laki Batak yang takut istri." Sihar, apakah kamu tidak memikirkan bahwa aku juga punya rasa bersalah pada orang tua?" (Saman: 27). Pada kutipan tersebut tampak bahwa keduanya menyadari perbuatan mereka adalah dosa. Berikut kutipan lain yang mendukung bahwa keduanya menyadari dosa: "Di perjalanan pulang dia bilang, sebaiknya kita tak usah berkencan lagi (saya tidak meyangka). 'Saya sudah punya istri. 'Saya menjawab, saya tak punya pacar, tetapi punya orang tua "Kamu tidak sendiri, saya juga berdosa. " (Saman: 4)

\section{Percaya Diri}

Rasa percaya diri merupakan suatu kondisi mental seseorang yang memberi keyakinan kuat pada dirinya untuk berbuat atau melakukan tindakan. Berikut merupakan rasa percaya diri yang dialami tokoh.

"Biarin. Paling tidak, aku bisa menyombongkan bahwa akulah satu-satunya dari kami berempat yang pertama kali melakukan hubungan seks kaarena sadar dan suka. Shakutala menghabiskan keperawanannya lebih karena pemberontakan. Dia tidak menikmatinya. Laila masih suci hama sampai sekarang. Dan Yasmin berbuat karena keterusan." (Saman: 97).

Kutian di atas merupakan diari yang ditulis oleh Cok satu di antara sahabat Yasmin dan Laila. Cok orang yang percaya diri dan sangat menikmati kebebasan hidupnya.

\section{Berlaku Adil}

Adil merupakan perlakuan yang tidak memihak, tidak sewenang-wenang, dan tidak berat sebelah. Keadilan atau ketidakadilan bias terjadi pada siapa pun akibat perlakuan memihak dari seseorang atau kelompok tertentu. Hal tersebut terlihat pada kutipan berkut. "Dunia ini penuh dengan orang-orang jahat yang tidak dihukum. Mereka berkeliaran. Sebagian karena tidak tertangkap. Sebagian lagi karena dilindungi, tak tersentuh hokum atau aparat." (Saman, 34).

\section{Bertindak hati-hati}

Bertindak hati-hati merupakan suatu perbuatan yang dilakukan agar tidak salah langkah atau mengambil keputusan. Atau sebuah sikap yang dilakukan agar tidak menyakiti hati orang lain. Seperti halnya pelarian yang dilakukan oleh Yasmin dan kawan-kawan dalam melarikan Saman. Kemudian, hal itu juga dilakukan Saman dalam menyampaikan beberapa keinginannya kepada Ayahnya. Berikut beberapa kutipan yang menggambarkan suatu tindakan yang dilakukan tokoh dengan berhati-hati.

Dalam surat kepada ayahnya Saman menulis, "Sembah pengabekti. Semoga surat kedua ini juga sampai ke tangan Bapak. Mohon pengaksama karena saya sudah membuat susah hati Bapak." (Saman: 160) Saman sangat berkata hatihati dalam suratnya sebab ia takut menyakiti hati bapaknya.

\section{Rasionalisasi Rancangan Implementasi}

Implementasi merupakan proses penerapan ide, gagasan, dan konsep suatu aktivitas pembelajaran sehingga mahasiswa menguasai kompetensi tertentu sebagai hasil interaksi dengan lingkungan (belajar). Hasil penelitian "Analisis Nilai Moral dalam Dwilogi Saman dan Larung karya Ayu Utami” akan diimplementasikan pada mata kuliah Kajian Fiksi Prosa Indonesia. Mata kuliah ini adalah sebuah penerapan yang mengajarkan mahasiswa agar memperoleh pengetahuan yang memadai tentang pembeda antara mengkaji dan mengapresiasi prosa fiksi, memahami unsurunsur dan struktur teks prosa fiksi, memberikan sumbangan berupa pendekatan dalam mengkaji prosa fiksi, serta dapat menerapkan nilai-nilai yang diperoleh pada penelitian terhadap kehidupan sehari-hari. 
Hasil penelitian ini dimplementasikan pada perguruan tinggi karena relevansi materi yang sesuai dengan usia mahasiswa antara 18-19 tahun. Mengingat bahasa yang digunakan dalam dwilogi novel Saman dan Larung agak vulgar maka mahasiswa dianggap lebih cocok dan mampu untuk memahami novel tersebut. Tambahan pula, apabila novel tersebut dibaca oleh mahasiswa tidak akan menimbulkan pertentangan secara moralitas. Sebaliknya, jika novel tersebut dibaca oleh anak (peserta didik) tingkat SMP atau SMA maka akan bertentangan dengan ketepatan dalam pemilihan materi pembelajaran. Artinya terjadi ketidaksesuaian antara bahan usia peserta didik dan sumber atau bahan pembelajarannya.

\section{SIMPULAN DAN SARAN}

\section{SIMPULAN}

Berdasarkan hasil analisis terhadap novel Saman dan Larung karya Ayu Utami maka dapat ditarik kesimpulan hasil penelitian didasarkan pada rumusan masalah. Nilai moral yang dilihat dari hubungan manusia dengan Tuhan dapat digolongkan menjadi beberapa hal, yaitu rasa takut akan Tuhan, tidak percaya/ragu akan Tuhan.

Nilai moral dilihat dari hubungan manusia dengan Masyarakat. Pada dasarnya manusia tidak dapat hidup sendiri. Ia hidup berdampingan di tengah-tengah masyarakat. Dalam masyarakat tentu ada perilaku yang harus dijaga bersama, misalnya kejujuran, persahabatan, tolongmenolong, kewajiban mengabdi kepada orang lain, dan hubungan (pergaulan) yang menyimpang.

Nilai moral kaitannya dalam hubungan manusia dalam masyarakat adalah jujur terhadap orang lain, pertalian persahabatan, tolong-menolong, kewajiban mengabdi kepada orang lain atau melaksanakan kewajiban dan perintah, saling mengenal, dan penyimpangan seksual.

Nilai moral dilihat dari hubungan manusia dengan Individu (diri sendiri). Nilai moral individual merupkan adanya hubungan manusia dengan dirinya sendiri. Dalam hal ini, kita dapat melihat bagaimana perasaan yang sedang dihadapi manusia atau tokoh dalam cerita ketika menghadapi persoalan-persoalan hidupnya. Adapun permasaahan yang dapat dilihat, yaitu pengendalian diri, takut berdosa atau bersalah, senang hidup sederhana, berani mengakui dosa, percaya diri, berlaku adil, dan bertindak hati-hati.

\section{SARAN}

Berdasarkan temuan dalam penelitian ini maka ada beberapa hal yang patut menjadi bahan pertimbangan dan renungan sehingga penulis akan menyarankan beberapa hal kepada pembaca.Pertama, para pembaca mampu mengapresiasi karya sastra. Karya sastra yang merupakan ekspresi jiwa pengarang dan tentu tidak lahir dari suatu kekosongan. Ada hal yang ingin disampaikan pengarang kepada pembaca. Oleh sebab itu, kita diharapkan mampu mengapresiasi karya-karya tersebut. Apresiasi diberkan dapat diberikan dalam bentuk apa pun. Satu di antaranya dengan membaca karya tersebut. Kedua, para membaca, selain mengapresiasi juga diharapkan mampu memahami makna dan pesan yang ingin disampaikan penulis kepada pembacanya. Dengan demikian, kita tidak sekadar membaca, tetapi sungguh menghayati makna karya sastra dan mampu mengimplementasikan nilai-nilai yang ada dalam karya tersebut ke dalam kehidupan sehari-hari. Ketiga, bagi para mahasiswa atau dosen, penelitian ini dapat digunakan sebagai acuan atau bahan pembelajaran saat perkuliahan. Hasil penelitian ini dapat digunakan sebagai contoh dan/atau media pembelajaran untuk mempermudah mahasiswa menganalisis prosa fiksi. Di sini, dapat dilihat langkah menganalisis dan pendekatan yang digunakan untuk menganalisis. Keempat, bagi peneliti selanjutnya, penelitian ini dapat dijadikan acuan atau referensi berkaitan dengan penelitian analisis nilai-nilai moral dalam novel.

\section{DAFTAR PUSTAKA}

[1] Aunurrahman. 2012. Belajar dan Pembelajaran. Bandung: Alfabeta

[2] Darmadi, Hamid.2012. Dasar Konsep Pendidikan Moral. Bandung: Alfabeta.

[3] Moleong, Lexy J. 1998. Metodologi Penelitian Kualitatif. Bandung: Remaja Rosdakarya

[4] Nurgiyantoro. 2010. Teori Pengkajian Sastra. Yogyakarta: Gajah Mada University Press

[5] Ratna, Nyoman Kutha. 2012. Teori, Metode, dan Teknik Penelitian Sastra. Yogyakarta: Pustaka Pelajar

[6] Sukmadinata, Nana Syaodih. 2011. Metode Penelitian Pendidikan. Bandung: PT Remaja Rosdakarya.

[7] Sayuti, Suminto A. 1997. Apresiasi Prora Fiksi. Jakarta: Depdikbud.

[8] Tarigan, Henry Guntur. 2011. Dasar-dasar PsikoSastra. Bandung: Angkasa.

[9] Utami, Ayu. 1998. Saman. Jakarta: Gramedia

[10] Utami, Ayu. 2001. Larung. Jakarta: Gramedia

[11] Wicaksono, Andri. 2014. Pengkajian Prosa Fiksi. Yogyakarta: Garudhawaca

[12] Widagdo, Joko. 2001. Sosiologi Sastra. Jakarta: Departemen Pendidikan dan Kebudayaan. 